\title{
Reconstruction of Tsunami Occurrence on Okushiri Island, Southwestern Hokkaido, Japan
}

\author{
Atsushi Urabe ( $\nabla$ urabe@gs.niigata-u.ac.jp ) \\ Niigata University https://orcid.org/0000-0002-8361-9794 \\ Yoshihiro Kase \\ Geological Survey of Hokkaido \\ Gentaro Kawakami \\ Hokkaido Prefecture: Hokkaido \\ Kenji Nishina \\ Hokkaido Prefecture: Hokkaido \\ Yasuhiro Takashimizu \\ Niigata Daigaku - Igarashi Campus: Niigata Daigaku \\ Hiroyuki Miyazawa \\ tolex

\section{Fumika Hirano} \\ Tohoku University: Tohoku Daigaku
}

\section{Full paper}

Keywords: tsunami deposit, tsunami recurrence, Okushiri Island, Hokkaido, Japan Sea

Posted Date: October 12th, 2021

DOl: https://doi.org/10.21203/rs.3.rs-951436/v1

License: (c) (i) This work is licensed under a Creative Commons Attribution 4.0 International License.

Read Full License 
1 Reconstruction of tsunami occurrence on Okushiri Island, southwestern Hokkaido,

2 Japan

3

4 Atsushi Urabe*

5 Research Institute for Natural Hazards and Disaster Recovery, Niigata University,

6 Ikarashi 2-8050, Nishi-ku, Niigata, Japan, 950-2181, urabe@gs.niigata-u.ac.jp

$7 \quad$ * corresponding author

8

9 Yoshihiro Kase

10 Geological Survey of Hokkaido, Hokkaido Research Organization, Kita 19, Nishi 11,

11 Kita-Ku, Sapporo, Japan, 060-0819, kase-yoshihiro@hro.or.jp

12

13 Gentaro Kawakami

14 Geological Survey of Hokkaido, Hokkaido Research Organization, Kita 19, Nishi 11,

15 Kita-Ku, Sapporo, Japan, 060-0819, kawakami-gentaro@hro.or.jp 
17 Kenji Nishina

18 Geological Survey of Hokkaido, Hokkaido Research Organization, Kita 19, Nishi 11,

19 Kita-Ku, Sapporo, Japan, 060-0819, nishina-kenji@hro.or.jp

20

21 Yasuhiro Takashimizu

22 Mathematical and Natural Sciences Course, Faculty of Education, Institute of Humanities,

23 Social Sciences and Education, Niigata University, Ikarashi 2-8050, Nishi-ku, Niigata,

24 Japan, 950-2181, takashimi@ed.niigata-u.ac.jp

25

26 Hiroyuki Miyazawa

27 Higashi-Nihon Sogo Keikaku Co.,Ltd, Narihira 3-14-4, Sumida-ku, Tokyo, Japan, 130-

28 0002, miyazawah@tolex.co.jp

29

30 Fumika Hirano

31 Department of Earth Science, Graduate School of Science, Tohoku University, Aoba 468-

32 1, Aramaki, Aoba-ku, Sendai, Japan, 980-8572, hirano.fumika.t7@dc.tohoku.ac.jp 
34 Indicate the corresponding author

35 Atsushi Urabe, urabe@gs.niigata-u.ac.jp 


\section{Abstract}

37 The eastern margin of the Japan Sea is located along an active convergent boundary

38 between the North American and Eurasian tectonic plates. Okushiri Island, which is

39 situated off the southwest coast of Hokkaido, is located in an active tectonic zone where

40 many active submarine faults are distributed. Studying the records of past tsunamis on

41 Okushiri Island is important for reconstructing the history and frequency of fault activity

42 in this region, as well as the history of tsunamis in the northern part of the eastern margin

43 of the Japan Sea. Five tsunami deposit horizons have been identified previously on

44 Okushiri Island, including that of the 1741 tsunami, which are interbedded in the coastal

45 lowlands and Holocene terraces. However, these known tsunami deposits date back only

$46 \sim 3,000$ years. A much longer record of tsunami occurrence is required to consider the

47 frequency of submarine fault activity. In this study, we cored from 7 to $25 \mathrm{~m}$ depth in the

48 Wasabiyachi lowland on the southern part of Okushiri Island, where previous studies

49 have confirmed the presence of multiple tsunami deposits on peat layer surfaces. The

50 results indicate that the Wasabiyachi lowland comprises an area that was obstructed by

51 coastal barriers between the lowland and the coast at $\sim 8.5 \mathrm{ka}$ and consists of muddy 
52 sediment and peat layers formed in lagoons and floodplains, respectively. In addition,

53 event deposits and 15 tsunami horizons were observed among the turbidites and peat

54 layers, dating back as far as 3,000 years. Combined with previous findings, Okushiri

55 Island has sustained 20 tsunami events between $\sim 7.5 \mathrm{ka}$ and the present. These findings

56 are critical for investigating the activities of submarine faults off the southwestern coast

57 of Hokkaido, as well as for determining tsunami risks along the coast of the Japan Sea

58 between North Tohoku and Hokkaido.

59

60 Keywords

61 tsunami deposit, tsunami recurrence, Okushiri Island, Hokkaido, Japan Sea

62

63 Main Text

64 1. Introduction

65 The 2011 Tohoku-Oki earthquake produced a tsunami that caused severe

66 damage to the Pacific coast of the Tohoku region (Japan Meteorological Agency, 2012).

67 Following the tsunami disaster, local governments along the coast of the Japan Sea have 
evaluated their tsunami risks by predicting tsunami heights in each region and by

69 reconstructing tsunami occurrence histories. In recent years, tsunamis in the Japan Sea

70 caused by the 1983 Middle Japan Sea earthquake, and the 1993 Hokkaido Nansei-Oki

71 earthquake have caused severe damage (Fig. 1). Among these, the 1983 Middle Japan

72 Sea earthquake $(\mathrm{Mj}=7.7, \mathrm{Mw}=7.7)$ that occurred off the coast of the Tsugaru region of

73 Aomori Prefecture produced a tsunami with high watermarks of over $10 \mathrm{~m}$ in the coastal

74 area that extended from Happo Town to the right bank of the Yoneshiro River in Akita

75 Prefecture, with a maximum upstream height of $14.9 \mathrm{~m}$ in Minehama, Happo Town.

76 Tsunamis have claimed over 100 lives in Akita and Aomori Prefectures (Japan

77 Meteorological Agency, 1984, Aomori Prefecture, 1984; Shuto, 1984; Abe and Ishii,

78 1987). The 1993 Hokkaido Nansei-Oki earthquake $(\mathrm{Mj}=7.8, \mathrm{Mw}=7.7)$ occurred off the

79 northwest coast of Okushiri Island, Hokkaido. High watermarks on Okushiri Island from

80 the tsunami were 10-20 m or higher at some locations. At Aonae, located at the southern

81 end of Okushiri Island, the tsunami arrived from the west and traveled northeast, with

82 maximum heights of more than 7-10 m. As a result, 198 lives were lost on Okushiri Island,

83 of which 109 were victims of the tsunami in the Aonae district (Geological Survey of 
84 Hokkaido, 1994; Japan Meteorological Agency, 1995). As the tsunami risks along the coast of the Japan Sea are currently being reevaluated, the Committee for Technical Investigation on Large-Scale Earthquakes in the

87 Sea of Japan (2014) (hereafter abbreviated as the Committee of the Japan Sea) has summarized the distribution of active submarine faults throughout the Japan Sea and created a rectangular model of tsunami sources based on previously collected seafloor geophysical data. Moreover, data relating to tsunamis produced by historical earthquakes

91 in the Japan Sea and research on tsunami deposits were compiled and assessed to reconstruct the historical record of tsunamis for each region (Committee of the Japan Sea, 2014). Furthermore, local governments along the coast of the Japan Sea have estimated

94 the local tsunami inundation, the tsunami risk for each region, and potential damage based on tentative modeling. However, compared to the Pacific coast, there are fewer historical records of earthquakes and tsunamis along the coast of the Japan Sea, making it difficult to clarify tsunami occurrence in the Japan Sea that can serve as a basis for tsunami risk evaluation. 
only along the coast of the Japan Sea, but also further off the Pacific coast of the Tohoku

101 region. However, reconstructing past tsunami occurrences, including events prior to 2011,

102 have been limited to tsunamis that occurred 2-3 ka (Minoura et al., 1987; Minoura and

103 Nakaya, 1990, 1991; Nanayama et al, 2000; Nishimura et al., 1999; Nishimura et al.,

104 2000; Kamataki et al., 2015, 2016, 2017, 2018a, b, 2019; Kase et al., 2016; Kawakami et

105 al., 2015; Okada et al., 2018, 2019). Because the period between events is short in terms

106 of the frequency of fault activity along the coast of the Japan Sea (approximately once

107 every few thousand years), it is necessary to investigate strata that date beyond a few

108 thousand years ago in addition to widely distributed tsunami deposits (Kawakami et al.,

109 2017b; Urabe, 2019; Takashimizu et al., 2020).

110

In this study, we investigated the Wasabiyachi lowland at the southern end of

111 Okushiri Island, Hokkaido, to observe and analyze tsunami occurrences between

112 Hokkaido and the North Tohoku coast prior to a few thousand years ago. The

113 Wasabiyachi River has a small drainage area that flows into Aonae Bay. Peat layers were

114 deposited on the surface of the Wasabiyachi lowland. According to Kase et al. (2016) and

115 Kawakami et al. (2017a, b), these peat layers ( 0-2 $\mathrm{m}$ depth) include four to five 
116 interbedded medium-grained sand layers that exhibit erosive bases and weak normally

117 graded structures. These sand layers have been determined to be tsunami-induced

118 deposits based on landward changes in grain size and layer thickness, as well as owing to

119 the paleocurrent, distribution, and characteristics of microfossils in the sand layers. The

120 estimated ages of the tsunami deposits observed on Okushiri Island are 1741 C.E., 0.8-

$1210.9 \mathrm{ka}, 1.5-1.6 \mathrm{ka}, 2.4-2.6 \mathrm{ka}$, and 2.8-3.1 ka (Kawakami et al. 2017a, b).

123 al. (2016) and Kawakami et al. (2017a, b) to examine tsunami-generated deposits older

124 than $3 \mathrm{ka}$. We identified event deposits related to 20 tsunami horizons, dating back to $\sim 7$

$125 \mathrm{ka}$, including the five tsunami deposits reported by Kase et al. (2016). This constitutes the

126 first reconstruction of tsunami occurrence along the coast of the Japan Sea off

127 southwestern Hokkaido. These findings are important for further extended

128 reconstructions of tsunamis in the Japan Sea from the coast of Niigata Prefecture to North

129 Tohoku. 


\section{2. Geologic and topographic setting}

\section{2.1. Okushiri Island}

136 Japan contains many reverse faults and is known as the Japan Sea Eastern Margin Mobile

137 Belt (Taira, 2002). The eastern margin of the northern Japan Sea is located at the

138 boundary between the North American and Eurasian (Amurian) tectonic plates (Seno et

139 al., 1996; Isozaki et al., 2010), and a compressive stress field has developed in this region

140 (Seno, 1999; Okamura, 2000). Therefore, many active onshore and submarine faults are

141 located within a short distance $(\sim 200-250 \mathrm{~km})$ from the coast to the offshore area of the

142 northern Tohoku to Hokkaido region (Fig. 1).

143 Okushiri Island is located on Okushiri Ridge, which extends $\mathrm{N}-\mathrm{S}$ in the

144 northern part of the Japan Sea Eastern Margin Mobile Belt. Previous studies have shown

145 that many active submarine faults are located around Okushiri Island. These faults

146 originally contributed to the expansion of the Japan Sea as normal faults, but have been

147 reactivated as reverse faults since the Quaternary (Okamura, 2010). The Committee of 
148 the Japan Sea (2014) investigated the continuities of active submarine faults that could

149 act as the source of a tsunami based on existing geological surveys of the seafloor and

150 obtained a rectangular model for the tsunami source faults. Tsunami source faults

151 between F06 and F24 were observed in the offshore regions extending from North

152 Tohoku to Hokkaido, which includes Okushiri Island. Among these faults is the

153 epicentral area of the 1993 Hokkaido Nansei-Oki earthquake, which is located northwest

154 of Okushiri Island (Fig. 1).

155

156 2.2. Wasabiyachi lowland

157 Okushiri Island has a long N-S trapezoidal shape with a perimeter of $84 \mathrm{~km}$.

158 The Wasabiyachi lowland is located north of the Aonae district at the southern end of

159 Okushiri Island. The Wasabiyachi lowland is a narrow lowland area, with a depth of $\sim 2$

$160 \mathrm{~km}$ and a width of 50-500 $\mathrm{m}$ and surrounded by an MIS 5c marine terrace that has an

161 elevation of 20-30 m (Fig. 2; Miyoshi et al., 1985). The base of the marine terrace

162 consists of marine mudstones and sandstones of Miocene to Neogene age (Miyoshi et al., 163 1985). 
165 elevation of $5 \mathrm{~m}$ and located $\sim 300-500 \mathrm{~m}$ from the present coastline. The Aonae coastal

166 sand dunes have an elevation of $\sim 10 \mathrm{~m}$ and occur along the present coast of the

167 Wasabiyachi River estuary (Hokkaido archaeological operations center, 2002). A beach

168 ridge comprising $\sim 5 \mathrm{~m}$ thick sand layers is located up to $\sim 100 \mathrm{~m}$ landward of the sand

169 dunes along the coast. Thus, the Wasabiyachi lowland is located in a topographic setting

170 that is separated from the coast by sand dunes and a sandy beach ridge (Fig. 2). Further,

171 the tidal level in Aonae at the southern end of Okushiri Island is $\sim 40 \mathrm{~cm}$ at high tide. The

172 tidal difference at Aonae is $\sim 20 \mathrm{~cm}$.

173

174 ------Figure 2------

175

176 3. Materials and methods

$177 \quad$ 3.1. Borehole sampling

Using a hand corer and excavating two pits, Kase et al. (2016) examined 
180 depths. Their results clarified the distributions of several layered tsunami deposits with

181 ages of up to $\sim 3,000 \mathrm{ka}$. In this study, we investigated deeper depths to observe tsunami

182 records with ages of up to $\sim 7,000-8,000 \mathrm{ka}$. A rotary corer and a rotating vibrational corer

183 were used for the excavations. Each core had an internal diameter of $86 \mathrm{~mm}$. Five core

184 excavations were made (sites OKU-1-OKU-5). Site OKU-1 (424’3.70” N, 139²7’2.86”

185 E, elevation $5.0 \mathrm{~m})$ was located near the coast in the lowlands. Site OKU-2 (424'4.60"

$186 \mathrm{~N}, 139^{\circ} 26^{\prime} 59.38^{\prime \prime}$ E, elevation $4.9 \mathrm{~m}$ ) is in the vicinity of the trial pit made by Kase et al.

187 (2016). Site OKU-3 (424'6.80" N, 139 $27^{\prime} 59.38^{\prime \prime}$ E, elevation $\left.5.0 \mathrm{~m}\right)$ is located at the

188 center of the lowland area. Sites OKU-4 (42 $4^{\prime} 8.86^{\prime \prime}$ N, 139 $26^{\prime} 59.77^{\prime \prime}$ E, elevation 5.2

$189 \mathrm{~m})$ and OKU-5 (424'10.29” N, $139^{\circ} 27^{\prime} 0.89^{\prime \prime} \mathrm{E}$, elevation $\left.5.2 \mathrm{~m}\right)$ were located further

190 inland (Fig. 2). The lengths of the cores collected from sites OKU-1 to OKU-5 were 23

$191 \mathrm{~m}, 7 \mathrm{~m}, 25 \mathrm{~m}, 17 \mathrm{~m}$, and $10 \mathrm{~m}$, respectively. The OKU-1 and OKU-2 cores extended

192 beyond the alluvium that constitutes the lowland strata and reached bedrock (Fig. 3).

\section{3.2. Core analyses}


196 photographed. Samples were collected for grain size and total sulfur (TS) analyses, as

197 well as dating.

199 laminated clay layer, every $1 \mathrm{~cm}$ in the silt layer, and every $1 \mathrm{~cm}$ in the sand layers in the

200 OKU-1 and OKU-3 cores. Samples were also collected every $1 \mathrm{~cm}$ in the sand layers in

201 the OKU-2, OKU-4, and OKU-5 cores. Samples were not collected from the humus layers

202 in any of the cores. The samples were pre-treated with a $10 \%$ hydrogen peroxide solution

203 to remove organic matter. Grain sizes were measured using a Mastersizer 3000 laser

204 diffraction-type grain size analyzer (Malvern Panalytical Ltd.).

206 OKU-2 core (2.6-20.0 m depth) at intervals of $20 \mathrm{~cm}$ and with a sample thickness of 1

$207 \mathrm{~cm}$. The samples were analyzed using an EMIA-120 sulfur analyzer (Horiba Ltd.).

Plant fragments were dated to obtain the corresponding layer ages using accelerator mass spectrometry (AMS) at the Accelerator Mass Spectrometry Co., Ltd.

210 (Shirakawa City, Fukushima Prefecture). The IntCal 20 (Reimer et al., 2020) database of 211 plant fragments and peaty samples and the OxCal v4.4.2 calibration program (Bronk 
212 Ramsey, 2009) were used to calculate the calibrated ages (Table 1). As a reference, two

213 samples were also dated (at Accelerator Mass Spectrometry Co. Ltd.) using shell pieces

214 and the data were corrected using a Marine 20 (Heaton et al., 2020) database (Table 1).

216 samples collected by Kase et al. (2016) from the Wasabiyachi lowland using the IntCal

21720 database and the OxCal v4.4.2 calibration program (Table 2).

218

219

------Table 1 and Table 2------

220

221 4. Results

222 4.1. Depositional facies

223

The OKU-1 and OKU-5 cores were divided into eight depositional facies,

excluding the uppermost topsoil and the basement bedrock (Fig. 3). In addition, well-

sorted sand layers, which indicate a depositional process that is distinctly different from

that of the regular depositional environment, were recorded separately as event deposits. 
$21.2 \mathrm{~m}$ depth, OKU-3: 20.0 - $25.0 \mathrm{~m}$ depth, OKU-4: $16.0-17.0 \mathrm{~m}$ depth). This

230 depositional facies comprises a fine to medium-grained gravel layer and a partially

231 organic silt layer. The gravel is poorly sorted and contains many light gray to green-gray

232 silty gravel that originated from the bedrock. The matrix of the gravel layer consists of 233 gray sandy silt and poorly sorted fine to medium-grained sand. The organic sandy silt

234 layer includes poorly sorted silty gravel of granule size.

$235 \quad$ 4.1.2. Facies FL2

237 depth, OKU-4: 14.6-16.0 m depth). It consists of a slightly poorly sorted organic sandy

238 silt layer that is interbedded with a poorly sorted fine to medium-grained sand layer with

239 a thickness of $\sim 3-5 \mathrm{~cm}$. The sandy silt layer may also contain a large amount of organic

240 matter and may be interbedded with a thin layer of organic matter. In addition, the upper

241 part of this facies consists of a $\sim 50 \mathrm{~cm}$ thick poorly sorted sandy silt layer, including silty

242 gravel with a granule to fine pebble size. 
247 gray silt to sandy silt layer is interbedded with a thin layer of clayey silt.

\section{4.1.4. Facies FL4}

251 OKU-5: 1.8-6.0 m depth). This facies consists of an upper dark brown peat layer and a

252 lower dark brown to light brown organic silt layer. This facies also includes

253 undecomposed plant material. No bioturbation was observed.

\section{$254 \quad$ 4.1.5. Facies FL5} depth, OKU-2: 0.5-0.9 m depth, OKU-3: 0.2-0.7 m depth, OKU-4: 0.2-0.5 m depth,

OKU-5: $0.3-1.8 \mathrm{~m}$ depth). This facies consists of a light brown to gray silt layer that 
bioturbation was observed.

\subsubsection{Facies LG1}

264 alternating gray silt and clayey silt layers. Only a small amount of bioturbation was

265 observed. Some thin laminated layers were observed.

\subsubsection{Facies LG2}

$\mathrm{m}$ depth, OKU-5: 6.0-8.3 m depth). This facies consists of a clayey silt layer in which

a $\sim 1 \mathrm{~mm}$ dark gray extremely fine-grained thinly laminated layer was observed, and is interbedded with a thin layer of clay or clayey silt with a thickness of $<5 \mathrm{~cm}$.

\subsubsection{Facies LG3}




\subsubsection{Facies BA1} to gray silty gravel of granule to fine pebble size. This facies did not contain plant material.

\subsection{Changes in grain size and total sulfur content in core OKU-3}

We measured the total sulfur content and grain size of the muddy sediment in core OKU-3, collected from the center of the Wasabiyachi lowland, to clarify any changes in the depositional environment, while excluding the gravelly facies near the basement and the humus layer at the top. The median grain size (Md), geometric mean grain size

289 (GM), mode grain size (Mo), and geometric standard deviation (Sorting) obtained from

290 the grain size analysis are shown in Figure 4. The Md and Sorting characteristics are 291 described below. 
293 grains of 10-20 $\mu$ m were observed at depths of 13.8-16.5 m (LG2). Slight variations of

$29410^{-30} \mu \mathrm{m}$ were observed at depths of 10.8-13.8 m (LG3). Slight variations of 10-40

$295 \mu \mathrm{m}$ were observed at depths of 5.0-10.8 m (LG2), except for the sand layer. Sizes of

$296 \quad 10-70 \mu \mathrm{m}$ were observed at depths of 3.0-5.0 m (FL4), in which large size variations

297 were observed (Fig. 4).

298

A Sorting of 3.3-4.5 was observed at depths of 16.5-20.0 m (FL2). A Sorting

of 3.0-4.0 (max 4.8) was mainly observed at depths of 13.8-16.5 m (LG2). Variations of

2.8-5.8 were observed at depths of 10.8-13.8 m (LG3). Slight variations of 3.3-4.8 were

observed at depths of 5.0-10.8 m (LG2), except for the sand layer. A Sorting of 3.4-4.5

302

was observed at depths of 3.0-5.0 m (FL4; Fig. 4). The Md and Sorting values of the

303

event deposits in cores OKU-1 through OKU-5 are described in section 4.3.

304

$\mathrm{SO}_{4}{ }^{2-}$ in water becomes $\mathrm{H}_{2} \mathrm{~S}$ owing to the action of sulfate-reducing bacteria

305

and is solidified in sediments as $\mathrm{FeS}_{2}$ (via FeS). Accordingly, the total sulfur content of

307 reducing capacity of the depositional environment. Core OKU-3 had a total sulfur content 
308 of $\sim 0.5 \mathrm{wt} . \%$ at depths of $16.5-20.0 \mathrm{~m}$ (FL2). While variations were observed, at depths

309 of $13.8-16.5 \mathrm{~m}$ (LG2) the total sulfur content was $2.0 \mathrm{wt} . \%$. At depths of $10.8-13.8 \mathrm{~m}$

310 (LG3), the total sulfur content was $\sim 3.0 \mathrm{wt} . \%$. At depths of 5.0-10.8 $\mathrm{m}$ (LG2), the lower

311 and upper portions had total sulfur contents of $5.0 \mathrm{wt} . \%$ and $2.0 \mathrm{wt} . \%$, respectively. At

312 depths of 3.0-5.0 m (FL4), the total sulfur content varied from 0.8 to $4.0 \mathrm{wt} . \%$. The results

313 indicate an overall total sulfur content of $\sim 0.5 \%$ between the deepest section and $16.5 \mathrm{~m}$,

314 excluding the data at $17.1 \mathrm{~m}$ (Fig. 4).

315

316

-------Figure 4------

317

318 4.2. Core sample age model

319

The radiocarbon ages of a total of 50 core samples were determined using plant

320

material, peaty sediment, and shell fragments (Table 1). All of the radiocarbon ages

conformed to the stratigraphic succession of each core. The ages of the horizons in each

core were estimated based on the interval sedimentation rates and the horizons for which

radiocarbon ages were obtained. Sedimentation rates were calculated for the upper and 
324 lower ranges of the calibrated ages $(2 \sigma)$. The thicknesses of the event deposits were

325 excluded from the interval sedimentation rate calculations because their deposition

326 occurred rapidly (Fig. 5).

327

328

-------Figure 5 ------

329

330 4.3. Event deposits

331

The sand layers observed in all cores were interbedded with the peaty layers

332 and muddy sediment, except for the gravel observed at the bottom of the cores (Figs. 3

333 and 4). A distinct boundary was also observed between the upper and lower facies of the

334 sand layers. This indicates that the sand layers were formed by a process different from

335 the typical depositional process in this environment. In this study, we defined an event

336 deposit as sediment with multiple characteristic facies, including basal erosion, abrupt

337 changes in grain size or degree of sorting, contamination with heterogeneous particles

338 such as plant fragments or mud clasts, and containing sedimentary structures such as

parallel or cross-lamination (Table 3). 
341 horizons were observed to a depth of $6.0 \mathrm{~m}$ (Fig. 3; Table 3). The upper three horizons

342 were fine to very fine-grained or fine to medium-grained sand layers with thicknesses of

$343 \quad 10-40 \mathrm{~mm}$, while the lower horizons were well-sorted coarse to medium-grained sand

344 layers with thicknesses of $100 \mathrm{~mm}$ to more than $300 \mathrm{~mm}$. Core OKU-2 had a shallower

345 bedrock depth compared to the other sites, with an alluvium thickness of $\sim 6.2 \mathrm{~m}$. Thirteen

346 event deposit horizons were observed in this core. While these event deposits included

347 some sand layers with thicknesses of $100 \mathrm{~mm}$ at horizons $<2.0 \mathrm{~m}$ deep, they consisted of

348 well-sorted fine to medium-grained sand layers with thicknesses of $\sim 5-20 \mathrm{~mm}$. Some thin

349 (7-50 mm) layers were observed at horizons deeper than $2.0 \mathrm{~m}$, but these were composed

350 of well-sorted fine to medium-grained sand layers with thicknesses of 150-340 mm (Fig.

351 3; Table 3). Fourteen event deposit horizons were observed in core OKU-3. While these

352 event deposits were composed of well-sorted medium-grained sand layers with

353 thicknesses of 4-30 mm, the horizons observed at depths of 7.79-10.4 m were

354 interbedded with a thick (270-1,400 mm) medium-grained sand layer (Figs. 3,4 and 6 ;

355 Table 3). Eight event deposit horizons were observed in core OKU-4. These event 
deposits were composed of well-sorted medium-grained sand layers with thicknesses of

$3574-210 \mathrm{~mm}$, the horizons observed at depths of 8.0-8.7 $\mathrm{m}$ were interbedded with a coarse

358 to medium-grained sand layer with a thickness of $600 \mathrm{~mm}$ (Fig. 3; Table 3). Ten event

359 deposit horizons were observed in core OKU-5, which was the site located furthest inland.

360 While these event deposits were interbedded with well-sorted medium to coarse-grained

361 sand layers with thicknesses of $20-190 \mathrm{~mm}$, the horizons at depths of 8.6-9.3 m were

362 interbedded with a well-sorted medium to coarse-grained sand layer with a thickness of

$363600 \mathrm{~mm}$ (Fig. 3; Table 3).

364

365

----- Figure 6 ------

366

367 5. Discussion

368 5.1. Depositional environments

Facies FL1 consists of very poorly sorted granule to fine pebble layers and

slightly sandy silt layers. The organic sandy silt layers also include silty gravel with a fine 
372 layers and is interbedded with a thin layer of poorly sorted fine to medium-grained sand

373 layers. The sandy silt layer contains large amounts of organic matter. These poorly sorted

374 gravel deposits, silty gravel, and turbidites that contain organic material indicate a

375 depositional environment that was affected by fluvial processes. Intercalated silty and

376 coarse sand layers indicate that deposition occurred in a small river channel and

377 floodplain. The facies succession and sedimentary features indicate that facies FL1 and

378 FL2 represent a fluvial depositional environment (Miall, 1992).

379

Facies FL3 consists of organic silt and sandy silt layers, while facies FL4

380 comprises organic silt and peat layers that contain undecomposed plant material. No

381 bioturbation was observed in either of these facies. Organic turbidites with no observed

382 bioturbation and peaty layers containing undecomposed plant material are indicative of a

383 freshwater swamp environment (Miall, 1992). In both of these facies, it is possible that

384 the fluvial channels were undeveloped swamps, as these facies did not include

385 interbedded sand layers.

Facies FL5 consists of silt layers that contain plant material and sandy silt layers,

387 and is interbedded with poorly sorted coarse-grained sand layers at the landward sites. As 
388 no bioturbation was observed and the facies contained thin layers of coarse-grained sand,

389 this depositional facies represents a small fluvial channel and floodplain depositional

390 environment (Miall, 1992).

392 were < $1 \mathrm{wt} \%$ (Fig. 4), indicating a non-reducing depositional environment that was not

393 affected by seawater. The depositional environment determined from the depositional

394 facies is consistent with implications of the total sulfur content.

Facies LG1-LG3 consist of thinly laminated clayey silt and silt layers. The

396 thinly laminated layers in LG2 and LG3 represent a typical lake environment where

397 surface disturbances do not extend to the bottom of the lake. The lack of bioturbation and

398 burrows also indicates a closed and reducing environment (Strum, 1979). LG2, which

399 contained a particularly thinly laminated interval, suggests that reducing conditions

400 persisted at the bottom. LG1 also contained silt, but some bioturbation was also observed.

401 This suggests that the water depth decreased and the number of aquatic organisms

402 increased. The succession and sedimentary features of these facies indicate a coastal

403 lagoon depositional environment. These facies also provide evidence for the 
404 development of a coastal sand barrier that separated the Japan Sea (Aonae Bay) from an

405 inland lagoon. Facies BA1 consists of well-sorted coarse to fine-grained sandy layers that

407 contain cross-bedding structures. Well-sorted sand layers indicate a depositional 408 environment that was strongly affected by a wave environment (Reinson, 1984). Beach 409 ridges that include sand dunes and ridges are located between the current Wasabiyachi 410 lowland and the Japan Sea, thereby blocking the Wasabiyachi lowland estuary. Because 411 of the differences between the depositional facies of the current environment and that of 412 the inland lagoon environment, BA1 may represent the coastal sand barrier depositional 413 environment.

\section{5.2. Wasabiyachi lowland depositional processes} We investigated the alluvium formation in the Wasabiyachi lowland based on

417 changes in the depositional facies and sediment ages in the cores. At the OKU-2 site,

418 bedrock was reached at $6.2 \mathrm{~m}$. Meanwhile, the bases of the alluvium aggrading the 419 lowlands at sites OKU-1, OKU-3, and OKU-4 can be estimated as over 20-25 m deep. 
420 Thus, the valley formation of the Wasabiyachi lowland occurred near sites OKU-1

421 through OKU-5 (Fig. 3). Fluvial material containing coarse gravel deposits (FL1 and

422 FL2) were deposited $\sim 9.5 \mathrm{ka}$. As sea level increased since the last glacial period near the

423 Japanese archipelago, sites OKU-1, -3, and -4 changed rapidly to a lagoon environment,

424 suggesting the presence of brackish water $8.5 \mathrm{ka}$. Moreover, as deposits that indicate a

425 lagoon environment were obstructed in horizons at 14.4-16.0 m deep in core OKU-1, it

426 is possible that a coastal barrier had already formed seaward of the surveyed area (Fig.

427 3). Since then, the obstructed lagoon environment expanded landward until $\sim 5.700 \mathrm{ka}$ at

428 the OKU-5 site in the valley, and until $\sim 5.2 \mathrm{ka}$ at the seaward OKU-1 site. The

429 depositional environment of this lagoon had a total sulfur content of $2-5$ wt.\% in the

430 deposits, indicating that it was heavily obstructed and hosted a strongly reducing

431 environment. Facies LG3 ( 7-7.3 ka) was observed at depths of $11.0-14.0 \mathrm{~m}$ in core

432 OKU-3 (Figs. 3 and 4). This indicates that the lagoon environment was at its most closed

433 at 7-7.3 ka. Moreover, the change in lagoon facies (from LG1 to LG3) indicates the

434 early stages of lagoon formation, the progression of aggradation, and the differences in

435 lagoon water depths from seaward to landward. 
437 Wasabiyachi lowland (estuary) was estimated to have formed $\sim 8.5 \mathrm{ka}$. Furthermore, due

438 to the observed barrier deposits at depths of $6.8-14.4 \mathrm{~m}$ in core OKU-1, the estuary

439 barriers can be estimated to have developed at $\sim 6-7.5 \mathrm{ka}$, then moved seaward thereafter 440 (Fig. 3). At $\sim 5.2 \mathrm{ka}$, aggradation of the entire lagoon progressed, altering the lagoon into

442 a freshwater-affected floodplain lowland (FL3) and a lowland with peat development.

443 Since $2 \mathrm{ka}$, the peaty lowlands have been altered to slightly dry land on the inland side 444 (and at some sites), and have become fluvial floodplains. topographic environment, the Wasabiyachi lowland is a depositional environment that

447 has been obstructed by coastal barriers in the estuaries from $\sim 8.5$ ka until the present. The deposits of this obstructed depositional environment are interbedded with deposits (sand layers) that suggest the events described above. 
At the study sites, the facies interbedded with event deposits were obstructed lagoons,

454 of the event deposits observed in each core (Table 3), assuming that the sedimentation

455 rate for each of these facies was generally constant. Among these, the sedimentary ages

456 matched within the age range for which the sedimentation is apparent, and the comparable

457 event deposits at the coring sites were named OW-4 to OW-20, thereby referencing the

458 deposit depth and facies characteristics (continuity of deposits that indicate thick layers).

459 Among these, event deposits OW-4 and OW-5 matched those identified as tsunami-

460 induced event deposits by Kase et al. (2016).

461 Among the event deposits interbedded in the cores, lateral changes in layer thickness

462 and particle size (Md and sorting) are shown in Figure 7 for deposits OW-4, -5, -8, -9, -

$46310,-12,-13$, and -14 , which are comparable in cores from three or more sites. In general,

464 sand layers with a thickness of $10 \mathrm{~cm}$ or more had different individual particle size

465 changes (as observed in the Md), but commonly exhibited upward fining. Sand layers that

466 were thick and could be divided into multiple units often exhibited upward fining in each 
occurred at many sites, with large variations. However, in some cases, the sorting tended was 300-400 $\mu \mathrm{m}$, but became $200-250 \mu \mathrm{m}$ landward, indicating fining. In particular,

474 the Md of OW-13 in core OKU-5 underwent a sudden change in fining. Meanwhile, the

475 sorting of these event sand layers was $\sim 2-3$ in core OKU-1 and $\sim 3$ on the landward side,

476 indicating that sorting did not change as much as Md. In addition, the sorting became

477 slightly worse as the layers thinned and grains became finer landward. These changes

478 indicate that sorting may have worsened due to the incorporation of fine terrigenous

479 particles as they flowed upstream (inland). The sand layer in OW-14 has a thickness of

$480 \sim 20 \mathrm{~cm}$ in core OKU-1, but became thicker in core OKU-3, and multiple units were observed. The layer thickness decreased by half landward. The Md was 280-360 $\mu \mathrm{m}$ in 
484 slight fining. However, the upward fining in each unit was unclear, and large variations

485 were observed throughout. Sorting also tended to become poor, as large variations were

486 observed at the landward sites (Fig. 7). and the grains tended to become finer landward. For reference, the Md of the sand layer at the present beach (foreshore environment) of the Wasabiyachi lowland estuary is 270 $340 \mu \mathrm{m}$, which is similar to the Md of the event layers in cores OKU-1 and OKU-2 near

491 the coast. In addition, the sorting of the present beach sand is $\sim 1.4$, which is better sorted 492 than the event sand layers. The lack of uniform event deposit layer thicknesses and grain 493 sizes with distance from the ocean indicates differences due to water mass speed during 494 an event, as well as differences in water depth in the depositional area (microtopography 495 of a lagoon or floodplain).

496 ------Figure 7---- 

Kase et al. (2016) conducted hand boring and dug trial pits up to $\sim 2 \mathrm{~m}$ in depth,

501 obtaining event deposits at five horizons (Ow-1 to Ow-5). The characteristics of these 502 event deposits included the following: 1) the layers become thinner and the grains become 503 finer landward; 2) they had a grain size composition similar to that of beach sand; 3) the 504 grain fabric of the sand layer indicated a landward paleo-flow direction; and 4) marine 505 dinoflagellate cysts and foraminiferal linings were present in the sand layer. In addition, 506 since the Wasabiyachi lowland has not experienced any flood damage from storm surges 507 or tsunamis in the last 300 years, we can conclude that the origin of these event deposits 508 was multiple tsunamis that occurred over time. Based on radiocarbon dating of the 509 deposits, the age of Ow-1 was 0.7-1.0 ka, Ow-2 and Ow-3 were 1.7-1.9 ka, Ow-4 was $510 \sim 2.6 \mathrm{ka}$, and Ow-5 was $~ 3.0 \mathrm{ka}$. Kawakami et al. (2017a, b) re-investigated the tsunami 511 history of the entire Okushiri Island (including the Wasabiyachi lowland) and named the 512 tsunami deposit caused by the sector collapse on Oshima-Oshima in 1741 as OK-1, Ow5131 of Kase et al. (2016) was named OK-2, Ow-2, and Ow-3 were named OK-3 ( 1.5 ka), 514 and Ow-4 and Ow-5 were named OK-4 and OK-5, respectively. OW-4 and OW-5 in the present study correspond to Ow-4 and Ow-5 in the Kase et al. (2016) study, and OK-4 
516 and OK-5 in the Kawakami et al. (2017a, b) studies, respectively. Note that the

517 radiocarbon dating calculations conducted by Kase et al. (2016) were revised according

518 to IntCal 09 (Raimer et al., 2009), and have since been recalculated according to IntCal

51920 (Raimer et al., 2020). As a result, the difference in the calibration ages $(2 \sigma)$ according

520 to IntCal 09 and IntCal 20 is approximately 10 to 80 years, which does not constitute a

521 major change to the chronological outline for Ow-1 to Ow-5 that was established

522 previously.

523

Overall, events deposits OW-6 to OW-20 exhibited thinner layers and finer

524 grains landward. In addition, the grain size composition of the sand layers interbedded at

525 seaward sites OKU-1 and OKU-2 were similar to those of the current beach sand. This

526 strongly suggests that the sand layers between OW-6 and OW-20 were derived from the

527 sea, and not inland regions. In addition, the sand layers of the lower deposits (OW-13 to

528 OW-20) were interbedded with the muddy sediment of an obstructed lagoon environment.

529 This lagoon deposit contains extremely thin laminated facies with no bioturbation,

530 indicating the presence of a closed lagoon in which sand layers that originated in the river

531 have not been transported. In contrast to this depositional environment, the sand layers 
532 between OW-13 and OW-20 indicate that they were transported to the lagoon over the

533 beach ridges that developed along the coast. The upper deposits (OW-6 to OW-12) are

534 interbedded with peat layers and muddy lowlands in a similar manner to Ow-4 and Ow-

535 5. The sand layers in these deposits (OW-6 to OW-12) have not been examined for marine

536 microfossils, as in Kase et al. (2016). However, these sand layers were interbedded in a

537 depositional environment in a similar manner to Ow-4 and Ow-5, suggesting that the

538 process of sand layer formation was the same. Accordingly, it is likely that event deposits

539 OW-6 to OW-20 observed in this study are tsunami deposits caused by tsunamis beyond

540 the beach ridges that have been surmised to have been present between the Wasabiyachi

541 lowland and the coast.

542

$543 \quad$ 5.5. History of tsunami events and potential tsunami sources

$544 \quad$ Kase et al. (2016) and Kawakami et al. (2017a, b) surveyed tsunami deposits in

545 the coastal lowlands of Okushiri Island and in the Hiyama region of Hokkaido. On

546 Okushiri Island, five horizons (OKU-1 to OK-5) were observed in peat layers that are

$547 \sim 3,000$ years old. Two horizons (HY-1 and HY-2) were also observed in the Hiyama 
548 region. In addition, turbidite layers at four horizons (ST-1 to ST-4) were observed in the

549 Shiribeshi Trough off the coast of Hokkaido, which have been established as turbidites

550 that originated from an earthquake (Shimokawa and Ikehara, 2002). Among these, OK-

551 1, HY-1, and ST-1 are tsunami deposits that were caused by the sector collapse on

552 Oshima-Oshima in 1741 (Satake, 2007; Satake and Kato, 2001), whereas OK-2, HY-2,

553 and ST-2 are deposits caused by tsunamis $~ 800$ years ago. In addition, it has been

554 suggested that OK-5 and ST-3 are sediments produced by a tsunami $\sim 3,000$ years ago.

555 According to previous studies, tsunami records in the Japan Sea off the southwestern

556 coast of Hokkaido contain only six horizons that extend to $\sim 3-3.5 \mathrm{ka}$, including the ST-

5574 event observed in the Shiribeshi Trough ( 3.5 ka; Kawakami et al., 2017a, b).

558 Of these previously identified horizons, the tsunami event $\sim 800$ years ago may

559 have been generated by F17 or F18 in the fault model by the Committee of the Japan Sea

560 (2014), based on similarities with the distribution of sedimentation caused by the 1741

561 tsunami (Kawakami et al., 2017) and source fault estimates based on numerical

562 calculations (Ioki et al., 2019). Thus, few studies of tsunami occurrence and their source

563 faults have been conducted in the Japan Sea off the southwestern coast of Hokkaido. 
and extended the record to $\sim 7.6 \mathrm{ka}$ (Fig.3 and Table 3). Until now, tsunami records in the northern Japan Sea from $\sim 7$ to 8 ka have only been observed in Lake Kamo, Sado Island, (Urabe, 2017). Future studies should compare the tsunami records and estimated tsunami sources for Okushiri Island, Hokkaido, and Sado Island, Niigata Prefecture.

\section{Conclusions} In this study, an extended coring survey was conducted in the Wasabiyachi

573 lowland on Okushiri Island, southeast of Hokkaido. Since beach ridges formed between

574 the Wasabiyachi lowland and the coast at $\sim 8 \mathrm{ka}$, peaty lowland deposits have been

575 continuously deposited in closed lagoons. Such topographical/geological environments are suitable for examining tsunami records that are much older than those researched to date. As a result, 17 deposits (OW-4 to OW-20) produced by offshore tsunamis were identified, and their ages were estimated. The results of this study can be used to 
581

\section{Declarations}

583 Ethics approval and consent to participate

584 Not applicable

585

586 Consent for publication

587 Not applicable

588

$589 \quad$ Availability of data and materials

590 Not applicable

591

$592 \quad$ Competing interests

593 There are no competing interests in relation with the present research.

594

$595 \quad$ Funding 
596 This study was supported by "Integrated Research Project on Seismic and Tsunami

597 Hazards Around the Sea of Japan" of MEXT (Ministry of Education, Culture, Sports,

598 Science and Technology in Japan). (PI: Masanao Shinohara, Co-PI: Atsushi

599 Urabe).

600

601 Authors' contributions

602 AU and YK contributed to writing the main part of the paper and re-

603 correction of age dating. AU, YK, GK, and NK did geological survey and

604 borehole sampling. YT carried out grain size analysis and sedimentological

605 interpretations. HM and FH carried out grain size and total sulfur quantity

606 analyses.

607

608 Acknowledgments

609 The authors thank appreciate the officers of Okushiri town hall and

610 landowner of the study area. 


\section{References}

613 Abe K, Ishii H. (1987) Distribution of maximum water levels due to the Japan Sea

614 Tsunami on 26 May 1983. J Oceanogr 43:169-182.

615 https://link.springer.com/article/10.1007/BF02109217.

616 Aomori Prefecture (1984) Record of disasters in the 1983 (Showa 58) Middle Japan Sea Earthquake. Department firefighting and disaster prevention of Aomori Prefecture, Aomori (In Japanese).

619 Bhattacharya JP, Walker RG, (1992) Deltas. In: Walker RG, James NP (eds.), Facies Models: Response to Sea-Level Change. Geological Association of Canada, pp $157-177$.

622 Committee for Technical Investigation on Large-Scale Earthquakes in the Japan Sea,

623 2014. Final report

of committee. https://www.mlit.go.jp/river/shinngikai_blog/daikibojishinchousa/houkoku/Repo rt.pdf. Accessed 30 September 2021, (In Japanese).

626 Geological Survey of Hokkaido (1994) The ground disaster, tsunami disaster caused by 
Hata M, Segawa S, Yajima J (1982) Geology of the Okushirito hokubu and nanbu district. English abstract).

632 Heaton JT, Köhler P, Butzin M, Bard E, Reimer WR, Austin ENW, Bronk Ramsey C, Grootes MP, Hughen A, Kromer B, Reimer JP, Adkins J, Burke A, Cook SM, curve $(0-55,000)$. Radiocarbon:62, $779-820$. https://doi.org/10.1017/RDC.2020.68.

637 Hokkaido archaeological operations center (2002) Report of Hokkaido archaeological operations center, part 2: Aonae dune site. Hokkaido archaeological operations center, Sapporo.

640 Ioki K, Tanioka Y, Kawakami G, Kase Y, Nishina K, Hirose W, Hayashi K, Takahashi R (2019) Fault model of the 12th century southwestern Hokkaido earthquake estimated from tsunami deposit distributions. Earth Planets and Space:71, 54. https://doi.org/10.1186/s40623-019-1034-6. 
644 Isozaki Y, Aoki K, Nakama T, Yanai S, (2010) New insight into a subduction-related orogen: a reappraisal of the geotectonic framework and evolution of the Japanese Islands. Gondwana Res:18, 82-105. https://doi.org/10.1016/j.gr.2010.02.015.1

647 Japan Meteorological Agency (1984) The report on the Nihonkai-Chubu earthquake, 1983. Technical report of Japan Meteorological Agency:106, 1-252 (In Japanese).

649 Japan Meteorological Agency (1995) Report on the Hokkaido-Nansei-Oki earthquake, 1993. Technical report of Japan Meteorological Agency:117, 1-281 (In Japanese).

651 Japan Meteorological Agency (2012) Report on the 2011 off the pacific coast of Tohoku (In Japanese).

654 Kamataki T, Abe N, Kanazawa S, Matsutomi H (2017) A study on paleo-tsunami inundation area and deposits in coastal lowland on the southern part of Akita Prefecture, the eastern margin of Japan Sea. J Japan Soc Civil Eng Ser B2 (Coastal Eng): 73, I_445-I_450. https://doi.org/10.2208/kaigan.73.I_445 (In Japanese with English abstract).

659 Kamataki T, Abe K, Kurosawa K, Miwa A, Imamura T (2015) Event deposits recorded 

in coastal lowland on the western coast of the Akita Prefecture, the eastern margin of Japan Sea. The Quatern Res (Daiyonki-Kenkyu):54, 129-138. https://doi.org/10.4116/jaqua.54.129 (In Japanese with English abstract).

663

Kamataki T, Matsutomi H, Umeda K, Abe K, Kurosawa H (2018a) Event deposits and their depositional ages recorded in coastal lowland along the eastern margin of the Japan Sea. Tohoku J Nat Dis Sci:54, 55-60 (In Japanese with English abstract). English abstract). tsunami history around the area affected by the 1983 Japan Sea Earthquake, coastal lowland on the northern part of Akita Prefecture, the eastern margin of Japan Sea. J Japan Soc Civil Eng Ser B2 (Coastal Eng):74, I_529 - I_534. https://doi.org/10.2208/kaigan.74.I_529 (In Japanese with English abstract) . 
676 Kamataki T, Unai H, Tokumaru T, Matsutomi H (2019) A study of paleo-tsunami history in coastal lowland on the southern part of Yamagata and northern part of Akita Prefectures, the eastern margin of Japan Sea. J Japan Soc Civil Eng Ser B2 (Coastal Eng):75, I_403-I_408. https://doi.org/10.2208/kaigan.75.I_403 (In Japanese with English abstract). and the Okhotsk Sea in Hokkaido, Japan. Special Report, Geological Survey of Hokkaido:42, 1-218 (In Japanese with English abstract).

686 Kawakami G, Kase Y, Urabe A, Takashimizu Y, Nishina K, (2017a) Tsunamis and 687 possible tsunamigenic deposits along the eastern margin of the Japan Sea. J Geol Soc Japan:123, 857-877. https://doi.org/10.5575/geosoc.2017.0054 (In Japanese with English abstract).

690 Kawakami G, Nishina K, Kase Y, Tajika J, Hayashi K, Hirose W, Sagayama T, Watanabe 
694 Koike K, Machida H (2001) Atlas of quaternary marine terraces in the Japanese islands. Univ. Tokyo Press, Tokyo (In Japanese).

Miall AD (1992) Alluvial deposits. In: Walker RG, James NP (eds.), Facies Models: Response to Sea Level Change. Geological Association of Canada, Waterloo, Ontario. pp.119-139.

Minoura K, Nakaya S (1990) Origin of Inter-Tidal Lake and Marsh Environments in and around Lake Jusan, Tsugaru. Mem Geol Soc Japan:36, 71-87 (In Japanese with English abstract).

Minoura K, Nakaya S (1991) Traces of tsunami preserved in inter-tidal lacustrine and marsh deposits: some examples from Northeast Japan. J Geology:99, 265-287. https://doi.org/10.1086/629488. 

English abstract).

709

710

711

712

713

714

715

716

717

718 Nishimura Y, Miyaji N, Yoshida M (1999) Survey of tsunami deposit along the western

719

720

721

722

723

Miyoshi M, Ota Y, Sawa H, Imaizumi T, Kashima K (1985) Holocene marine terraces of Okushiri island, off the western Hokkaido, Japan. Geographical Review of Japan Ser A:58, 596-608. https://doi.org/10.4157/grj1984a.58.9_596 (In Japanese with English abstract).

Nanayama F, Shigeno K, Satake K, Shimokawa K, Koitabashi S, Miyasaka S, Ishii M (2000) Sedimentary differences between the 1993 Hokkaido-nanseioki tsunami and the 1959 Miyakojima typhoon at Taisei, southwestern Hokkaido, northern Japan. Sediment Geol:135, 255-264. https://doi.org/10.1016/S00370738(00)00076-2. coast of north Hokkaido, Japan. Historical Earthquake:15, 255-231 (In Japanese with English abstract).

Nishimura Y, Suzuki M, Miyaji N, Yoshida M, Murata D (2000) Deposit of historical tsunami identified at Ayukawa coast, Kumaishi, Oshima Peninsula, Hokkaido. Chikyu Monthly (Special issue):82, 147-153 (In Japanese). 
724 Okada R, Kaji J, Umeda K, Kamataki T, Ishida M, Uchidate M (2018) Event deposits recorded the Lake Jusanko, Tsugaru Peninsula. Tohoku J Nat Disas Sci:54, 49-54 (In Japanese with English abstract).

727 Okada R, Umeda K, Kamataki T (2019) Traces of tsunami and liquefaction recorded around the Lake Jusan, Tsugaru Peninsula. Tohoku J Nat Disas Sci:55, 25-30 (In Japanese with English abstract).

730 Okamura Y (2000) Inversion tectonics along the eastern margin of the Japan Sea, J Japan English abstract).

733 Okamura Y (2010) Relationship between geological structure and earthquake source faults along the eastern margin of the Japan Sea. Journal of the Geological Society of Japan:116, 582-591. https://doi.org/10.5575/geosoc.116.582 (In Japanese with English abstract).

737 Reimer PJ, Austin WEN, Bard E, Bayliss A, Blackwell PG, Bronk Ramsey C, Butzin M, 

hemisphere radiocarbon age calibration curve (0-55 cal kBP). Radiocarbon:62, 725-757. https://doi.org/10.1017/RDC.2020.41.

746 Reimer PJ, Baillie MGL, Bard E, Bayliss A, Beck JW, Blackwell PG, Bronk Ramsey C, Hajdas I, Heaton TJ, Hogg AG, Hughen KA, Kaiser KF, Kromer B, McCormac FG, Manning SW, Reimer RW, Richards DA, Southon JR, Talamo S, Turney CSM, van der Plicht J, Weyhenmeyer CE (2009) IntCal09 and Marine09 Radiocarbon Age Calibration Curves, 0-50,000 Years cal BP. Radiocarbon:51, 1111-1150. https://doi.org/10.1017/S0033822200034202. 
756 Satake K (2007) Volcanic origin of the 1741 Oshima-Oshima tsunami in the Japan Sea.

757 Earth Planet and Space:59, 381-390. https://doi.org/10.1186/BF03352698.

758 Satake K, Kato Y (2001) The 1741 Oshima-Oshima eruption: extent and volume of 759 submarine debris avalanche. Geophys Res Lett:28, 427-430. https://doi.org/10.1029/2000GL012175.

761 Seno T (1999) Syntheses of the regional stress fields of the Japanese islands. Island Arc:8, 762 66-79. https://doi.org/10.1046/j.1440-1738.1999.00225.x.

763 Seno T, Sakurai T, Stein S (1996) Can the Okhotsk Plate be discriminated from the North 764 https://doi.org/10.1029/96JB00532.

766 Shimokawa K, Ikehara K (2002) Chapter 6, The paleo-earthquake recorded to sediment. In: Otake M, Taira A, Ota Y (eds) Active faults and seismo-tectonics of the eastern margin of the Japan Sea. Tokyo University Press, Tokyo. pp. 95-108 (In Japanese).

769 Shuto N (1984) Trace highs of tsunami of the Japan Sea Earthquake of 1983. Report of tsunami laboratory, Tohoku Univ:1, 88-267 (In Japanese).

771 Strum M (1979) Origin and composition of clastic varves. In: Schlucher C (ed.) Moraines 
773 Taira A (2002) Active Faults and Seismo-Tectonics of the Eastern Margin of the Japan eastern margin of the Japan Sea. Tokyo University Press, Tokyo. pp 38-61 (In Japanese).

777 Takashimizu Y, Kawakami G, Urabe A (2020) Tsunamis caused by offshore active faults 778 and their deposits. Earth-Sci Rev:211, 103380. https://doi.org/10.1016/j.earscirev.2020.103380.

780 Urabe A (2017) Reconstruction of tsunami history based on event deposits in the Niigata area, eastern coast of the Sea of Japan. Quart Int:456, 53-68. https://doi.org/10.1016/j.quaint.2017.05.045.

783 Urabe A (2019) Examination of tsunami history based on the sediment survey in the Japan 784 Sea side, South-West Japan. Report of the Coordinating Committee for Earthquake Prediction Japan:102, 420-421 (In Japanese). 
788 Figure 1 Distribution of the active faults in the offshore between Aomori to Hokkaido, northern part of Japan Sea (Committee for Technical Investigation on Large-Scale Earthquakes in the Sea of Japan, 2014). Okushiri island is located at the offshore Oki earthquake) occurred in this area.

794

795

Figure 2 Topography around the Wasabiyachi lowland, Aonae region, southern part of of southwest Hokkaido, and active faults is distributed over the surrounding sea. Lage earthquake (1983 Middle Japan Sea earthquake and 1993 Hokkaido Nanseigeomorphologic classification of landforms is based on Hata et al. (1982) and Koike and Mchida (2001). The Wasabiyachi lowland along the Aonae Bay is barriered by Holocene marine terrace and coastal beach ridge with sand dune. Contour maps are reproduced from online map of the Geospatial Information Authority of Japan (GSJ). 
803 Figure 3 Geological log of the OKU-1 - OKU-5 cores, 14C ages and event deposits.

804 Seventeen event deposits (tsunami sand beds: OW-4 - OW-20) are well correlated

805 in the Wasabiyachi lowland (see Figure 2 for location).

806

807 Figure 4 Vertical changes of grain size analysis and content of total sulfur of the OKU-

808 3 core. The grain size analysis showed Md (median grain size), G.M. (geometric

809 mean grain size), Mo (mode grain size) and sorting (geometric standard deviation) in the figure.

811

812 Figure 5 Age-depth curve of the OKU-1 - OKU-5 cores with estimated ages of event deposits. The vertical axis of the graph shows the depth and thickness of event deposits. The horizontal axis shows the calibrated age value to clearly indicate the correlation of the event deposits.

816

817 Figure 6 Photograph of lithofacies and event deposits in depth $0-15 \mathrm{~m}$ of the OKU-3 
826 Figure 7 Stratigraphic correlation and changes of lithofacies, Md (median grain size), and sorting (geometric standard deviation) of the event deposits (OW-4, -5, -8, -9, $-10,-12,-13$, and -14$)$.

829

830 Table $1{ }^{14} \mathrm{C}$ age summary of the OKU-1 to OKU-5 cores. Age ranges are calibrated using IntCal 20 and Marine 20.

833 Table $2{ }^{14} \mathrm{C}$ age dating of the Wasabiyachi lowland reported by Kase et al. (2016). Kase 

ages carried out re-calibration using IntCal 20.

836

837 Table 3 Description of lithofacies and estimated age of the event deposits for the OKU-

$838 \quad 1$ to OKU-5. 


\section{Figures}

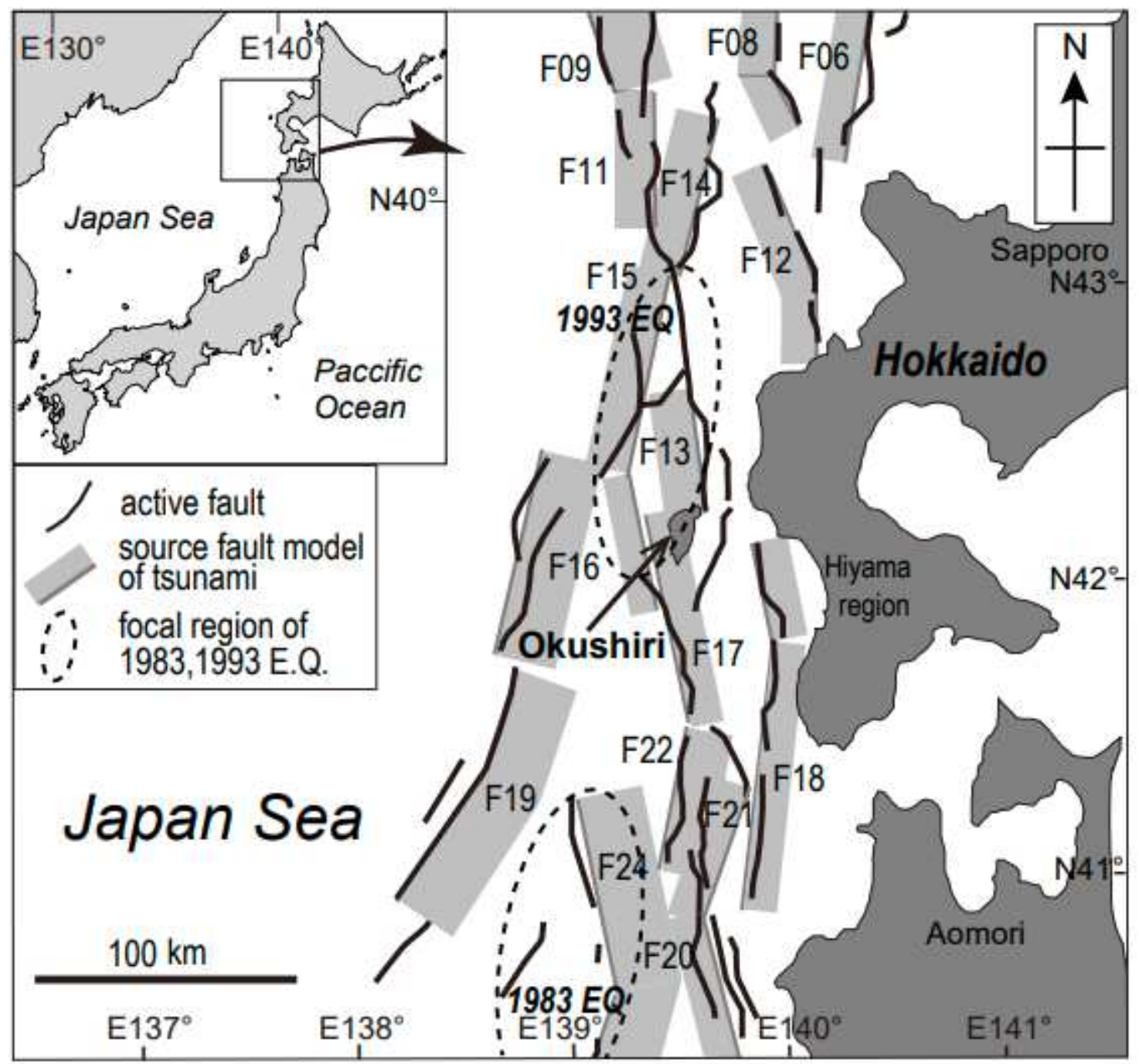

Figure 1

Distribution of the active faults in the offshore between Aomori to Hokkaido, northern part of Japan Sea (Committee for Technical Investigation on Large-Scale Earthquakes in the Sea of Japan, 2014). Okushiri island is located at the offshore of southwest Hokkaido, and active faults is distributed over the surrounding sea. Lage earthquake (1983 Middle Japan Sea earthquake and 1993 Hokkaido Nansei囚793 Oki earthquake) occurred in this area. 


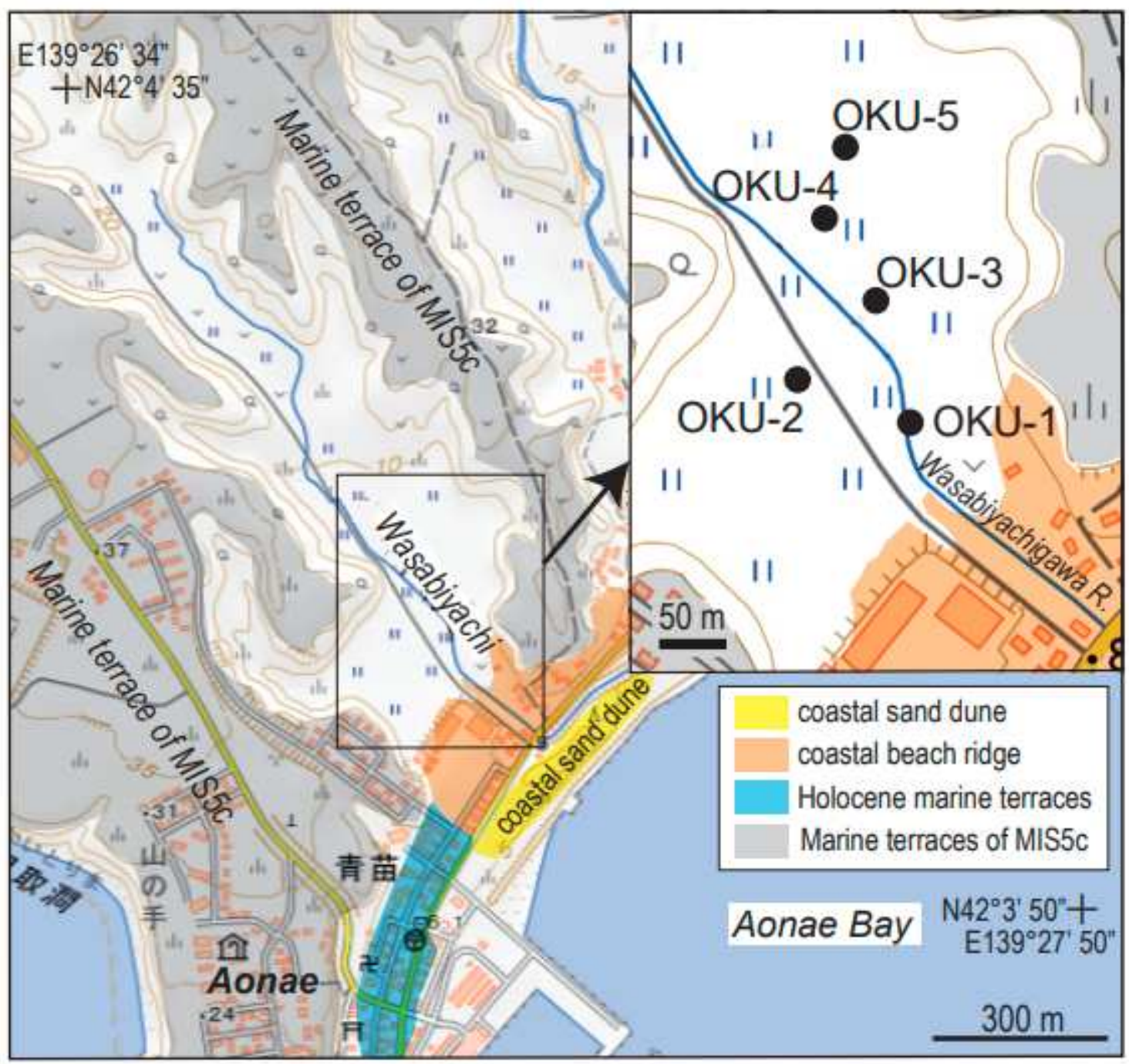

Figure 2

Topography around the Wasabiyachi lowland, Aonae region, southern part of Okushiri island. Index map shows the localities of borehole sites. Geologic and geomorphologic classification of landforms is based on Hata et al. (1982) and Koike and Mchida (2001). The Wasabiyachi lowland along the Aonae Bay is barriered by Holocene marine terrace and coastal beach ridge with sand dune. Contour maps are reproduced from online map of the Geospatial Information Authority of Japan (GSJ). 


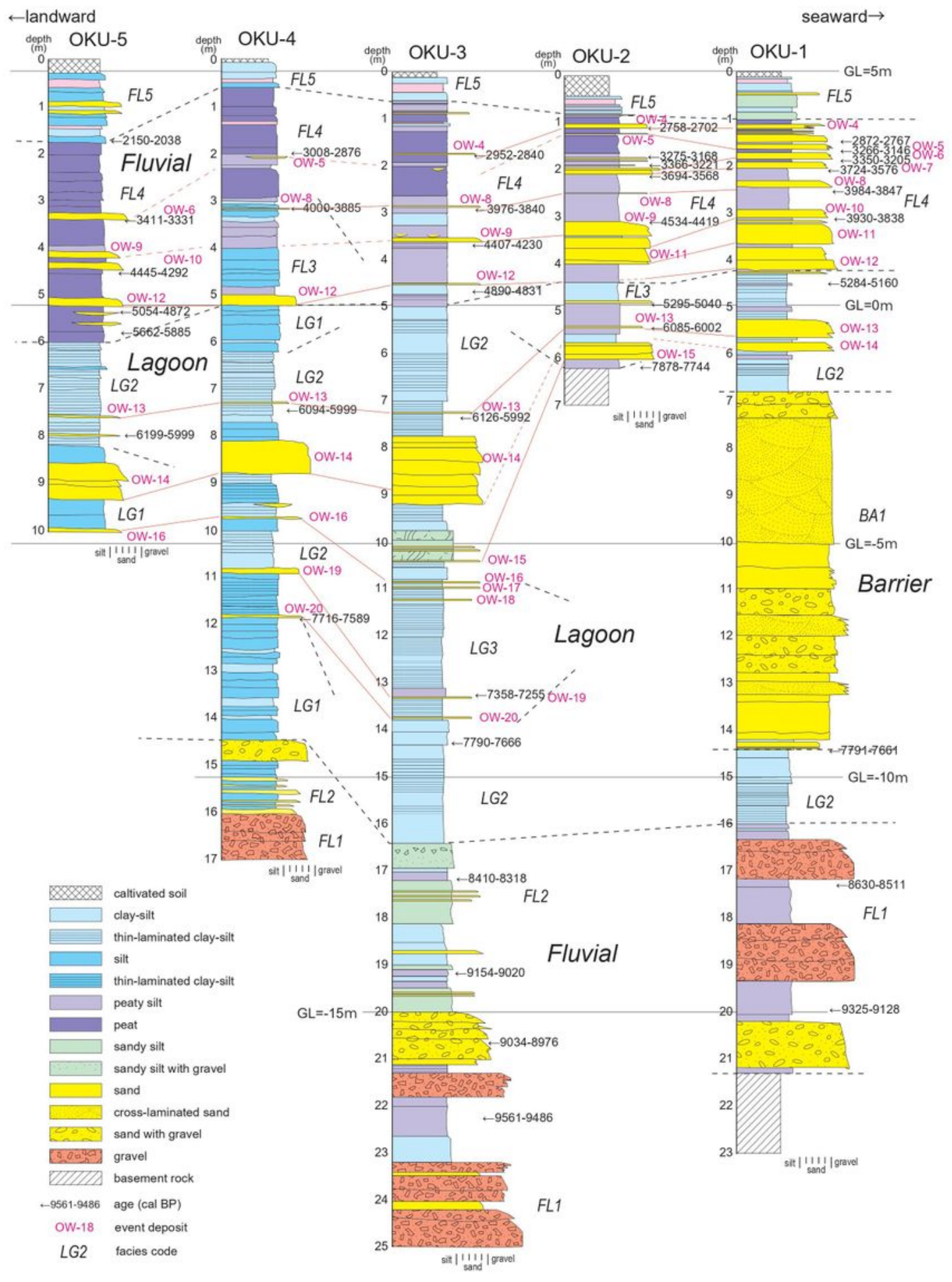

\section{Figure 3}

Geological log of the OKU-1 - OKU-5 cores, $14 \mathrm{C}$ ages and event deposits. Seventeen event deposits (tsunami sand beds: OW-4 - OW-20) are well correlated in the Wasabiyachi lowland (see Figure 2 for location). 

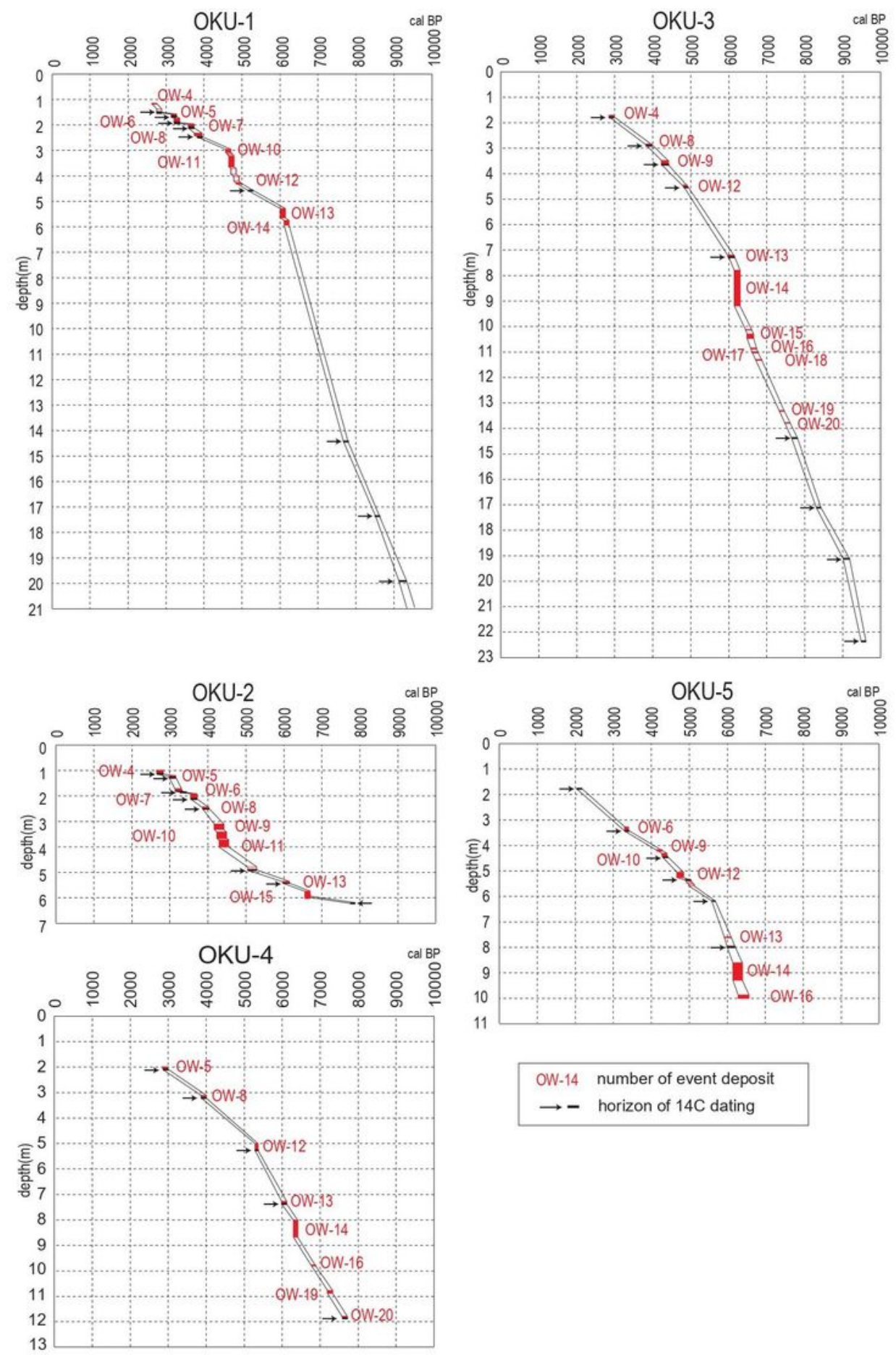

OW-14 number of event deposit

$\rightarrow-$ horizon of $14 \mathrm{C}$ dating

\section{Figure 4}

Vertical changes of grain size analysis and content of total sulfur of the OKU-3 core. The grain size analysis showed Md (median grain size), G.M. (geometric mean grain size), Mo (mode grain size) and sorting (geometric standard deviation) in the figure. 


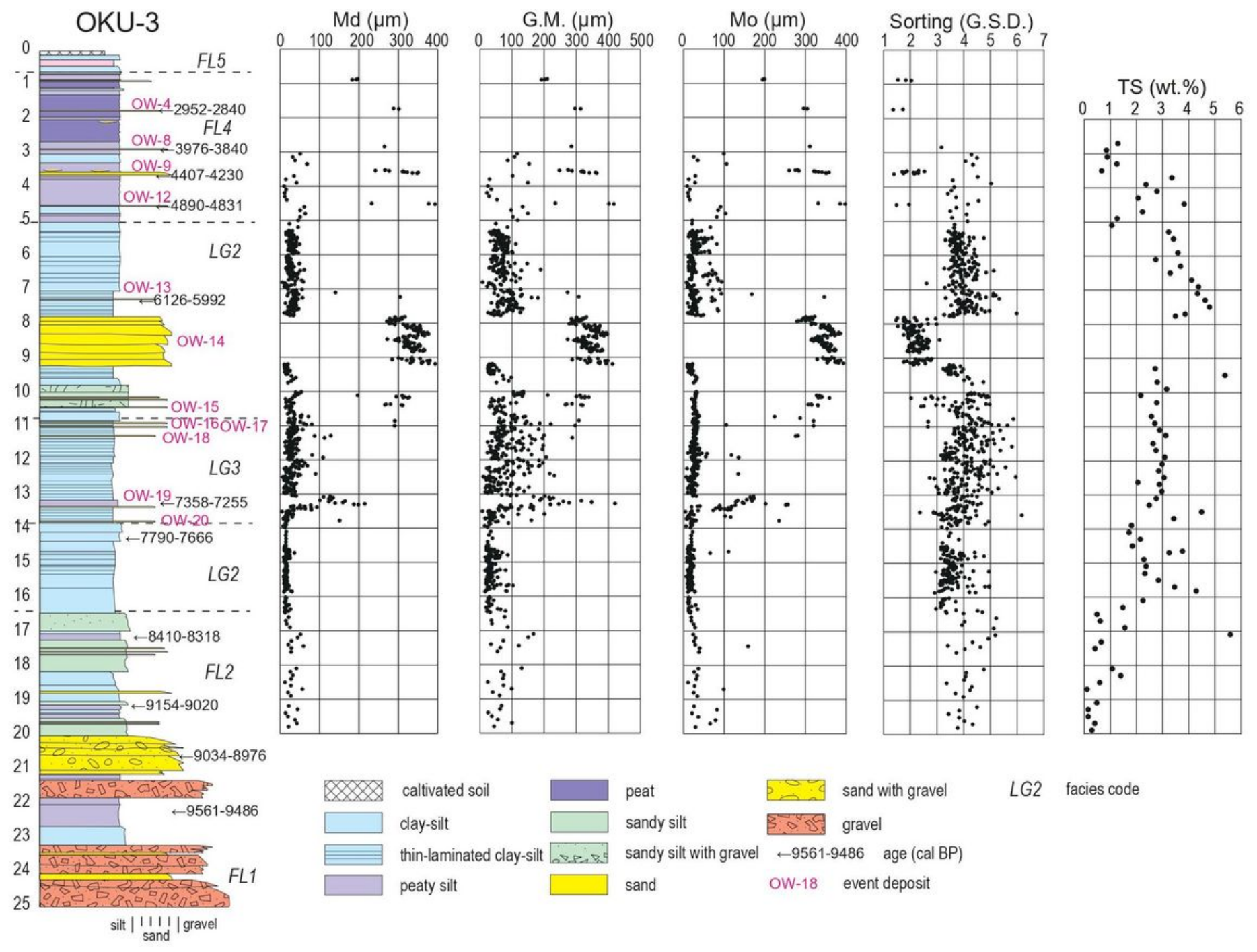

Figure 5

Age-depth curve of the OKU-1 - OKU-5 cores with estimated ages of event deposits. The vertical axis of the graph shows the depth and thickness of event deposits. The horizontal axis shows the calibrated age value to clearly indicate the correlation of the event deposits. 


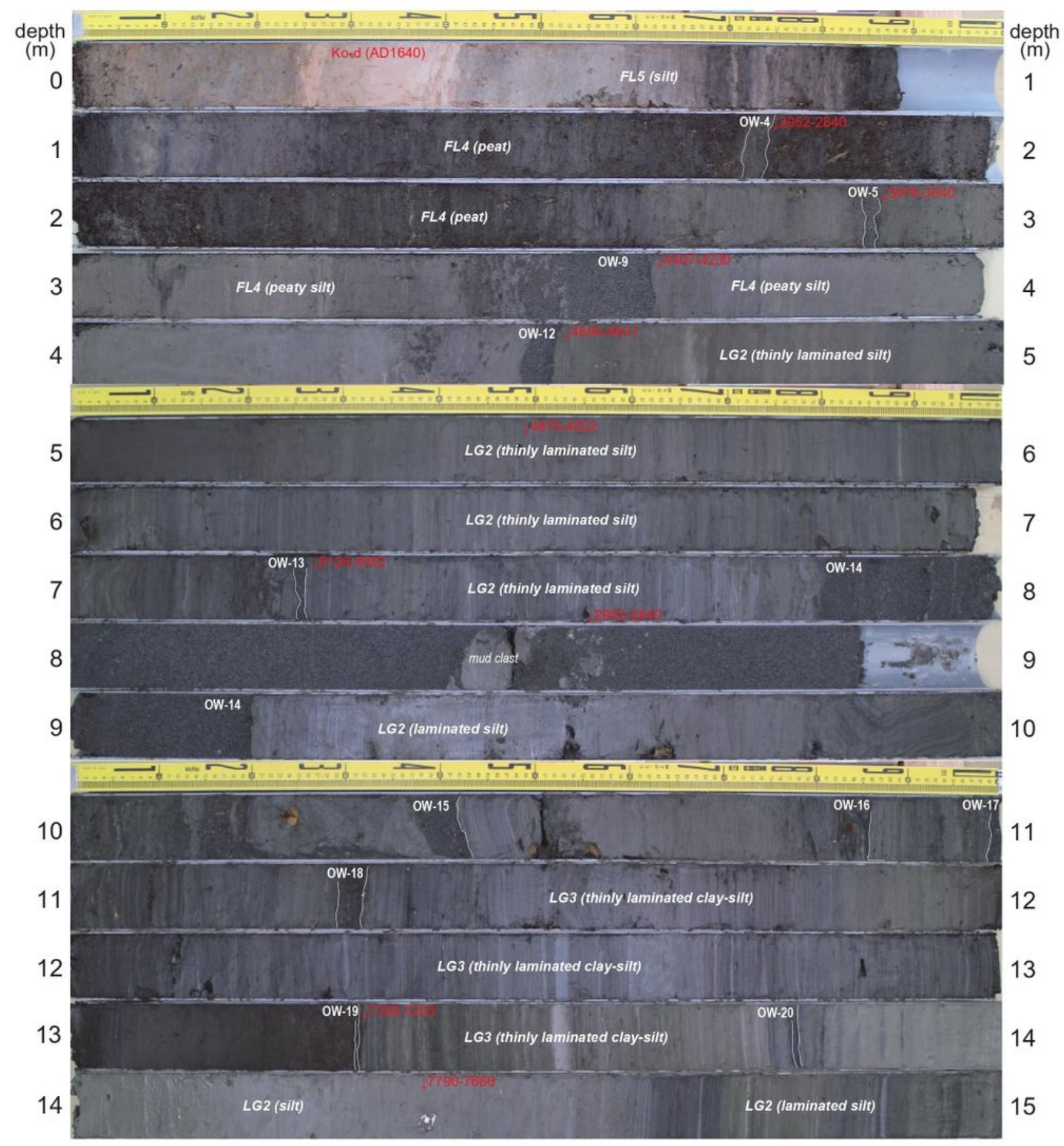

\section{Figure 6}

Photograph of lithofacies and event deposits in depth $0-15 \mathrm{~m}$ of the OKU-3 core. The event deposits are consisted of well-sorted sand layer. The lithofacies of event deposits are clearly different from the steady depositional environment. The facies code of LG2 and LG3 show laminated silt and clay-silt of occlusive lagoon. The FL4 and FL5 show peaty environment of fluvial floodplain. The Ko-d (AD 1640 Komagatake- 
d tephra) is widely distributed in the southern part of Hokkaido, and this tephra is compared in the Okushiri area (Kase et al. 2016 and Kawakami et al. 2017a).

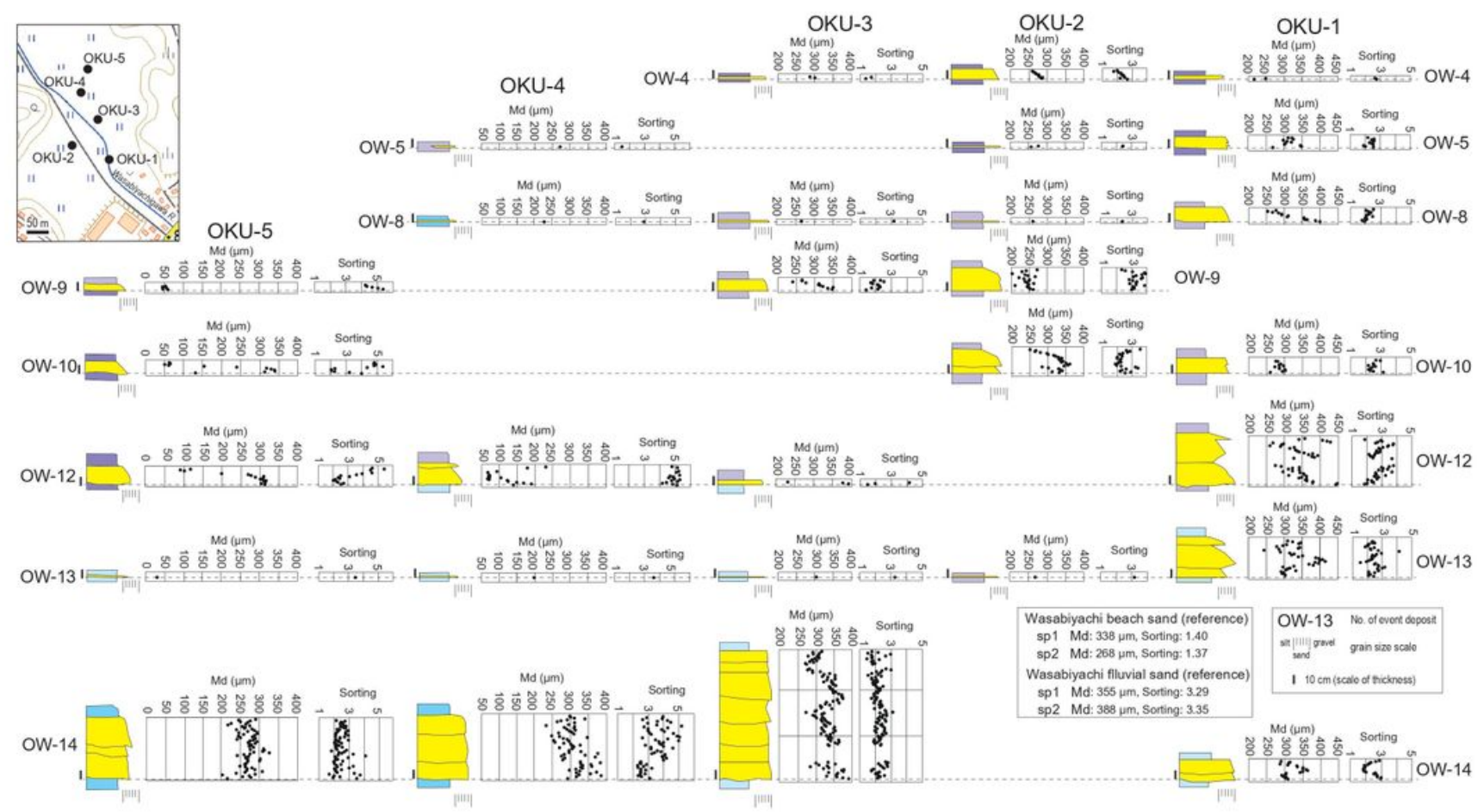

Figure 7

Stratigraphic correlation and changes of lithofacies, Md (median grain size), and sorting (geometric standard deviation) of the event deposits (OW-4, $-5,-8,-9,-10,-12,-13$, and -14$)$.

\section{Supplementary Files}

This is a list of supplementary files associated with this preprint. Click to download.

- Table1urabe.xlsx

- Table2urabe.xlsx

- Table3urabe.xIsx

- graabst.jpg 